\title{
The anniversary conference "Forest science for a sus- tainable forestry and human well-being in a changing world" - Bucharest, September 18-21 2018
}

\author{
Ovidiu Badeaş, Ecaterina Nicoleta Apostol, Marius Teodosiu, Dănuț Chira, Lucian Dincă, \\ Nicolai Olenici
}

Badea O., Apostol E.N., Teodosiu M., Chira D., Dincă L., Olenici N., 2018. The anniversary conference "Forest science for a sustainable forestry and human well-being in a changing world" - Bucharest, September 18-21 2018. Ann. For. Res. 61(2): 127-128.

Authors. "Marin Drăcea“ National Research and Development Institute in Forestry, 128 Eroilor Av., 077190 Voluntari, Ilfov, Romania.

§ Corresponding author: Ovidiu Badea (obadea@icas.ro)

Manuscript received November 4, 2018; revised December 26, 2018; accepted December 29, 2018; online first December 31, 2018.

Since its establishment in 1933 when, for the first time, the institutionalized scientific research of forests began in Romania, the Research and Experimentation Institute in Forestry - at present, "Marin Drăcea" National Research and Development Institute in Forestry (INCDS), named after its founder - is an essential unit contributing to the development of forest science in Romania. Despite all the obstacles encountered over time, remarkable achievements in forest science can be attributed to its activity - research, scientific debates or publications about forests. Nowadays, the institute is looking to ensure an increased quality and competitiveness in research, to find solutions for the promotion of and experimentation with sustainable development measures in forestry, both in a national and European context.

Between the $18^{\text {th }}$ and the $21^{\text {st }}$ of September 2018 , the institute celebrated its $85^{\text {th }}$ foun- dation anniversary with a special event, in a year of great historic importance for Romania - Centenarian of the 1918 Great Union of the Romanian historical provinces. This special event - The International Scientific Conference "Forest Science for a Sustainable Forestry and Human Well-being in a Changing World" INCDS "Marin Drăcea" 85 Years of Activity, Centenarian of the Great Union in 1918" - has been organized under the patronage of the Romanian Ministry of Research and Innovation and was supported by prestigious foreign institutions - International Union of Forest Research Organizations (IUFRO), the United Nations International Cooperative Programme on Assessment and Monitoring of Air Pollution Effects on Forests (ICP Forests) or The Romanian Academy, "Gheorghe Ionescu Sisești" Academy of Agricultural and Forestry Sciences, The Ministry of Waters and Forests, The Ministry of Environment, all from Romania. 
230 participants, representing international organizations, universities or research institutes from 16 countries (Argentina, Australia, Croatia, England, France, Germany, Italy, Lithuania, Moldova, Romania, Serbia, Slovakia, Thailand, Turkey, The US, Switzerland) attentended the event. The presentations included major topics of forest research: climate change, the impact of air pollution or of biotic and abiotic stressors, nature conservation, genetics, adaptive management, modelling and mapping of forest ecosystems and their services or new Earth-Observation technologies applied in forests. The scientific papers debated actual issues in forest science and its role in promoting a sustainable forest management and an improvement of quality of life, in the global context of environmental changes.

In this issue of Annals of Forest Research the readers will find papers of Conference - presentation of a national forest strategy, methods to promote biodiversity by forest works, a first extended report on an invasive species, assessments in Long-Term Ecological Research (LTER) sites, modern tools for forest measurements or measures for re-colonization and an active management of a wild species. We hope that this issue of Ann. For. Res. will be a good reference for scientists and will contribute to the international promotion of the forest sciences, emphasizing the link between them and practice, in a changing environment and society.

We thank to all the participants for their scientific contributions and we are indebted to the Editorial Board of Annals of Forest Research for their assistance in preparation and publication of this issue. Now, we are looking forward to the next conference, having the same aims of promoting the forest science, for a better environment and a better quality of life. 